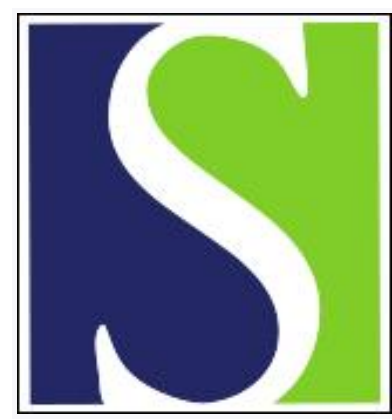

Scand J Work Environ Health 1983;9(3):253-258

https://doi.org/10.5271/sjweh.2412

Issue date: Jun 1983

Increased uptake of serotonin in platelets from car painters occupationally exposed to mixtures of solvents and organic isocyanates.

by Beving H, Malmgren R, Olsson P, Tornling G, Unge G

This article in PubMed: www.ncbi.nlm.nih.gov/pubmed/6612266

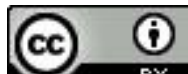


Scand $j$ work environ health 9 (1983) 253-258

\title{
Increased uptake of serotonin in platelets from car painters occupationally exposed to mixtures of solvents and organic isocyanates
}

\author{
by Håkan Beving, PhD, ${ }^{1}$ Rigmor Malmgren, DrMedSc, ${ }^{1}$ Per Olsson, MD, ${ }^{1}$ \\ Göran Tornling, MD, ${ }^{2}$ Gunnar Unge, MD²
}

\begin{abstract}
BEVING H, MALMGREN R, OLSSON P, TORNLING G, UNGE G. Increased uptake of serotonin in platelets from car painters occupationally exposed to mixtures of solvents and organic isocyanates. Scand $j$ work environ health 9 (1983) 253-258. Twelve car painters occupationally exposed to mixtures of solvents and organic isocyanates were investigated concerning serotonin uptake in platelets. The data from the exposed workers were compared to data from a reference group consisting of 50 nonexposed volunteers. The mean platelet count in whole blood of the exposed workers was markedly lower than the corresponding value of the reference group. Three workers had values below the lower limit of the $95 \%$ tolerance interval of the referents. In both groups the serotonin transport strictly obeyed Michaelis-Menten's simple saturation kinetics. Nine of the twelve exposed workers had uptake rates which were significantly higher $(p=0.05)$ than those of the referents. The obtained data suggest that the present method may be used to reveal early organ damage, prior to the appearance of clinical symptoms, due to intermittent exposure to organic solvents and isocyanates.
\end{abstract}

Key terms: 5-hydroxytryptamine, organic solvents, uptake kinetics.

Platelets have proved to be suitable model cells for presynaptic neurons $(18,26)$. Among the several striking resemblances are possession of an excitable cell membrane sensitive to environmental changes $(1,15,18)$ and the specific uptake and storage of serotonin $(10,12,27)$.

We have recently developed a technique for making kinetic measurements of serotonin transport in human platelets. This method permitted characterization of a transport disorder in piatelets from patients with endogenous asthma (14).

Organic solvents are known to exert toxic effects, particularly on the central nervous system and blood-forming organs $(7,20,29)$. Car painters are exposed to a mixture of organic solvents and chemicals

1 Department of Experimental Surgery, Karolinska Institute, Stockholm, Sweden.

2 Department of Thoracic Medicine, Karolinska Hospital, Stockholm, Sweden.

Reprint requests to: Prof P Olsson, Department of Experimental Surgery, Thoracic Clinics, Karolinska Hospital, S-10401 Stockholm, Sweden.
(5). The garage routine involves, in addition to color mixing and spray-painting, grease removal and grinding, filling with isocyanate-containing putty and hardeners, and frequent cleaning of various tools and the worker's own hands. The main solvents used are, in order of use, methyln-butyl-ketone, white spirit (17-22\% aromatics, methyl benzenes included), toluene, methylene chloride, and sometimes trichloroethane and trichloroethylene (5).

As mentioned, the workers are exposed to isocyanates, which are one of the components in hardeners. The isocyanates are toxic to mucosa membranes, especially conjunctiva and the respiratory tract $(3$, 22, 28). Long-term exposure to low concentrations of organic isocyanates may cause asthma-like reactions $(3,16,17)$. The isocyanates react in vitro with free amino groups and other sites on protein molecules. The reaction products may be similar to derivatives formed in vivo which cause immunogenic and/or allergenic symptoms in exposed workers (28). With hydrolysis hexamethylene diisocyanate, 
which was present in low amounts in the hardeners used by the workers in the present study, yields hexamethylenediamine, a toxic substance, the fumes of which have been shown to cause respiratory difficulties in exposed rats (6).

Since isocyanates occasionally lead to a specific form of severe asthma and patients with endogenous asthma show serotonin uptake kinetics which do not adhere to Michaelis-Menten's saturation kinetics (14), we found it of interest to investigate whether concomitant exposure to solvents and organic isocyanates in any way influences serotonin transport in platelets from occupationally exposed car painters.

\section{Material and methods}

\section{Material}

The ACD solution used in the analyses was $1.37 \mathrm{~g}$ of citric acid, $2.5 \mathrm{~g}$ of sodium citrate, and $2.0 \mathrm{~g}$ of anhydrous glucose per $100 \mathrm{ml}$ of distilled water. The $\mathrm{pH}$ of the solution was 4.5 (Karolinska Pharmacy, Stockholm). 5-Hydroxy-(2-14 C)tryptamine creatinine sulfate $\left({ }^{14} \mathrm{C} 5-\mathrm{HT}\right)$, specific activity $58 \mathrm{mCi} / \mathrm{mmol}$ (2.15 GBq/mmol, Radiochemical Centre, Amersham, United Kingdom) was used in the incubation of the platelet-rich plasma. The ethanol added by the manufacturer was removed by freezedrying, and the residue was dissolved in $0.9 \%$ saline. Soluene $100^{\circledR}$ (protein solubilizer) and Instagel ${ }^{\circledR}$ (scintillation liquid) (Packard Instrument, Co, Downers Grove, IL, United States) were also used in the analyses.

For the platelet-rich plasma, blood samples from a cubital vein were taken with a 1.4-mm wide stainless steel cannula and distributed into seven polystyrene centrifuge tubes containing citrate solution (ACD $1 \mathrm{ml}$ ). Nine milliliters of blood was added to each tube. Immediate centrifugation at $190 \times \mathrm{g}$ for $15 \mathrm{~min}$ at room temperature and decanting of the plasma followed.

\section{Blood donors}

Twelve men (age range 21-52 years), employed in the car painting industry and exposed daily to solvents and organic isocyanates, were studied. The investigations were conducted on Tuesday and Wednesday mornings. Fifty volunteers (32 women and 18 men, age range 25-51 years) from the staff of different wards of the Thoracic Clinics, Karolinska Hospital, served as referents and were examined during the same period as the car painters. The volunteers included in this study were participating in a current investigation concerning the platelet serotonin uptake kinetics of healthy people. In the reference data no differences in the kinetic parameters of the men and women have been observed. No intake of any drug was permitted for $10 \mathrm{~d}$ prior to the taking of the blood samples. The exposed workers were interviewed regarding abnormal fatigue, irritability, symptoms from the respiratory tract, or allergic manifestations.

\section{Experimental procedure}

The experiments were performed between 45 and $60 \mathrm{~min}$ after the taking of the blood samples. Platelet-rich plasma $(0.9 \mathrm{ml})$ was prewarmed for $5 \mathrm{~min}$ at $37^{\circ} \mathrm{C}$ and then incubated for $60 \mathrm{~s}$ at $37^{\circ} \mathrm{C}$ with $20 \mu \mathrm{l}$ of the ${ }^{14} \mathrm{C} 5$-HT solution. The final result was five concentrations ranging from 0.1 to 2.0 $\mu \mathrm{mol} / \mathrm{l}$ (15). Each concentration was run in triplicate. The reaction was interrupted with $0.1 \mathrm{ml}$ of $15 \%$ formaldehyde $-4.5 \%$ disodium ethylenediamine tetraacetic acid solution, and the samples were placed in an ice bath (4). An aliquot (0.2 ml) of each platelet-rich plasma sample was transferred to a counting vial containing $1 \mathrm{ml}$ of Soluene/isopropanol $(1+1)$ and left for digestion for $30 \mathrm{~min}$ at room temperature. Thereafter $15 \mathrm{ml}$ of Instagel I/0.5-mol/1 hydrochloric acid $(9+1)$ was added, and the radioactivity was determined in a liquid scintillation spectrometer (Tricarb 2425, Packard Instrument Co). The remaining platelet-rich plasma was centrifuged for $30 \mathrm{~min}$ at $20,000 \times \mathrm{g}$ at $4^{\circ} \mathrm{C}$. An aliquot $(0.2 \mathrm{ml})$ of the resulting platelet-free plasma $\left(<1 \times 10^{9}\right.$ platelets $\left./ 1\right)$ from each sample was transferred to a polyethylene counting vial. Fifteen milliliters of the scintillation liquid was added, and the radioactivity was determined. The platelet bound activity ( $\mathrm{v}, \mu \mathrm{mol} / \mathrm{l})$ was calculated by the subtraction of the amount of ${ }^{14} \mathrm{C}$ activity in platelet-free plasma from that in platelet-rich plasma, the latter of which represents the total activity $(\mathrm{C}, \mu \mathrm{mol} / \mathrm{l})$. 
Table 1. Age, platelet number in whole blood and platelet-rich plasma (PRP), and the following kinetic parameters: the correlation coefficient in the Scatchard analysis $[r(S)]$, the index of heterogeneity according to Sips $(\alpha)$, the concentration of serotonin needed to achieve half the maximum uptake rate $\left(K_{m}\right)$, and the maximum uptake rate when the carrier is saturated ( $\left.V_{\max }\right)$ for 12 solvent-exposed workers, as well as the $95 \%$ tolerance interval for the 50 referents.

\begin{tabular}{|c|c|c|c|c|c|c|c|}
\hline \multirow{3}{*}{$\begin{array}{l}\text { Case } \\
\text { number }\end{array}$} & \multirow{3}{*}{$\begin{array}{c}\text { Age } \\
\text { (years) }\end{array}$} & \multirow{2}{*}{\multicolumn{2}{|c|}{$\begin{array}{l}\text { Platelelets } \\
\left(\times 10^{-9 / 1)}\right.\end{array}$}} & \multicolumn{4}{|c|}{ Kinetic parameters } \\
\hline & & & & \multirow[t]{2}{*}{$r(S)$} & \multirow[t]{2}{*}{$\alpha$} & \multirow{2}{*}{$\begin{array}{c}\mathrm{K}_{\mathrm{m}} \\
(\mu \mathrm{mol} / \mathrm{l})\end{array}$} & \multirow{2}{*}{$\begin{array}{c}\sqrt{\max } \\
\left(\text { pmol }^{\prime} \cdot 10^{6}\right. \\
\text { platelets } \\
\left.-1 \cdot \min ^{-1}\right)\end{array}$} \\
\hline & & Blood & PRP & & & & \\
\hline 1 & 24 & 124 & 268 & -0.856 & 0.927 & 1.14 & $2.51^{a}$ \\
\hline 2 & 22 & 228 & 412 & -0.949 & 0.991 & 1.85 & $3.49^{\mathrm{a}}$ \\
\hline 3 & 22 & 145 & 383 & -0.961 & 0.988 & 1.18 & 1.98 \\
\hline 4 & 35 & $117^{a}$ & 256 & -0.860 & 0.957 & 1.58 & $3.52^{\mathrm{a}}$ \\
\hline 5 & 23 & 135 & 274 & -0.958 & 0.983 & 1.43 & $3.56^{\mathrm{a}}$ \\
\hline 6 & 39 & 171 & 331 & -0.969 & 0.990 & 1.65 & $3.32^{\mathrm{a}}$ \\
\hline 7 & 38 & 174 & 345 & -0.884 & 0.957 & 1.18 & 1.79 \\
\hline 8 & 51 & 125 & 281 & -0.940 & 0.980 & 1.07 & $2.48^{a}$ \\
\hline 9 & 23 & $115^{a}$ & 350 & -0.941 & 0.983 & 1.60 & $3.10^{a}$ \\
\hline 10 & 20 & 129 & 335 & -0.967 & 0.988 & 1.57 & $3.11^{\mathrm{a}}$ \\
\hline 11 & 36 & 219 & 496 & -0.861 & 0.935 & 1.11 & 1.47 \\
\hline 12 & 29 & $85^{\mathrm{a}}$ & $184^{a}$ & -0.929 & 0.983 & 1.43 & $4.86^{a}$ \\
\hline Mean & $\cdot$ & 150 & 309 & ' & 0.972 & 1.40 & 2.93 \\
\hline SD & & 44 & 110 & & 0.022 & 0.26 & 0.93 \\
\hline \multicolumn{2}{|c|}{ Mean (referents) } & 220 & 451 & -0.910 & 0.966 & 1.20 & 1.47 \\
\hline \multirow{2}{*}{\multicolumn{2}{|c|}{$\begin{array}{l}95 \% \text { tolerance } \\
\text { intervals for } \\
\text { referents }(N=50)\end{array}$}} & & & & & & \\
\hline & & $\begin{array}{l}118 \& \\
332\end{array}$ & $\begin{array}{l}206 \& \& \\
696\end{array}$ & $\begin{array}{l}-0.785 \& \\
-0.973\end{array}$ & $\begin{array}{l}0.904 \& \\
1.002\end{array}$ & $\begin{array}{l}0.44 \& \\
1.96\end{array}$ & $\begin{array}{l}0.52 \& \\
2.42\end{array}$ \\
\hline
\end{tabular}

a Values outside the $95 \%$ tolerance interval.

The platelet count in the whole blood and plasma samples was determined by electronic cell counting (Linson $431 \mathrm{~A}$, LIC Instrument, Sweden).

\section{Calculations}

The adherence of the experimental data to Michaelis-Menten's simple saturation kinetics was ascertained by linearization methods according to Scatchard \& Sips $(23,25)$. The kinetic parameters $V_{\max }$ (pmol/106 platelets $/ \mathrm{min}$ ), ie, the maximum uptake rate when the carrier is saturated, and $\mathrm{K}_{\mathrm{m}}(\mu \mathrm{mol} / \mathrm{l})$, ie, the concentration of serotonin needed to achieve half the maximum uptake rate, were obtained according to Lineweaver \& Burk (9). The combined use of these mathematical methods has earlier been described by us $(11,12)$. Ninety-five percent tolerance intervals (mean $\pm 2.28 \times \mathrm{SD}$ ) were calculated for the Scatchard correlation coefficient $[\mathrm{r}(\mathrm{S})]$, the index of heterogeneity $(\alpha)$ in the Sips analysis, and the $K_{m}$ and $V_{\text {max }}$. Since a tolerance interval covers a certain part of a population ( $95 \%$ ) with a certain nominal probability, $5 \%$ values falling outside the limits of the intervals were considered significantly abnormal.

\section{Results}

None of the exposed workers complained of irritability or exhibited symptoms that could be related to massive solvent exposure. They were therefore considered on par with the reference group in regard to general health.

The $95 \%$ tolerance intervals for the platelet count in whole blood, the correlation coefficient in the Scatchard analysis, the index of heterogeneity according to Sips, the $K_{m}$, and the $V_{\max }$ from the reference group are presented in table 1 . The first two mentioned parameters show that the platelets from the reference subjects always displayed a saturable serotonin transport mechanism (fig 1). 


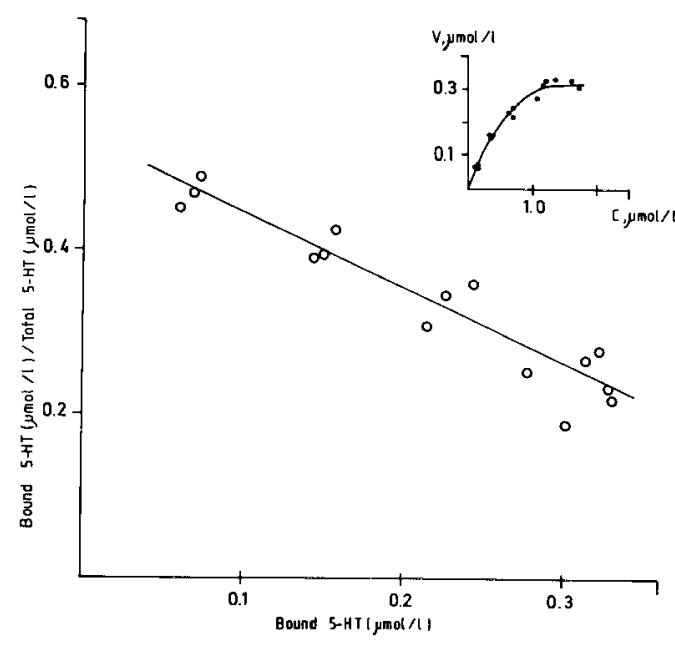

Fig 1. Scatchard plot of the serotonin (5-HT) uptake in platelet-rich plasma from one referent.

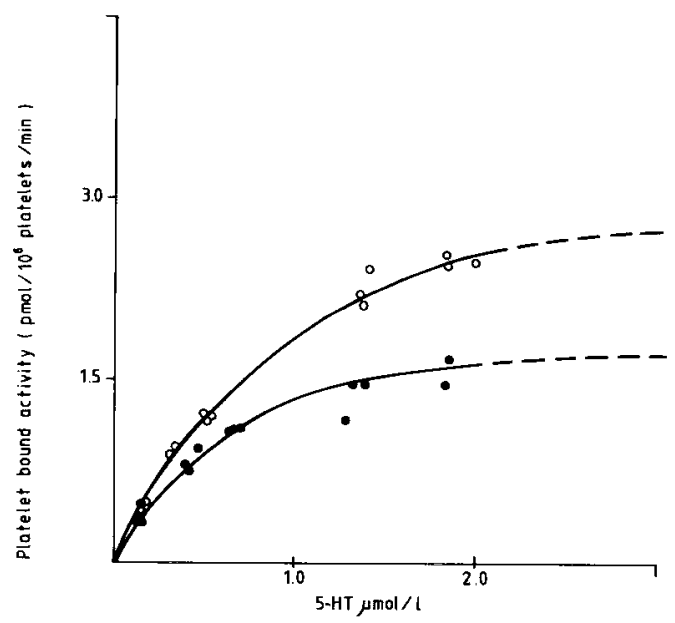

Fig 2. Michaelis-Menten's plot of the serotonin (5-HT) uptake in platelet-rich plasma from one referent $\left(336\right.$ platelets $\left.\times 10^{9} / 1\right)(-)$ and case $6\left(331\right.$ platelets $\left.\times 10^{9} / 1\right)(\mathrm{O}-\mathrm{O})$.

The mean value of the platelet count in whole blood from the solvent-exposed workers was markedly lower than the corresponding value of the reference group, and three workers had values outside the lower limit of the tolerance interval of the referents (table 1).

The serotonin uptake by platelets from the subjects exposed to solvents adhered also in all respects to a saturable mode of serotonin transport, ie, both the correlation coefficient in the Scatchard analysis and the index of heterogeniety according to Sips were within the tolerance intervals of the referents (table 1, fig 1). Nine of the twelve exposed workers had $V_{\max }$ values that were however outside the upper limit of the tolerance interval of the referents; this phenomenon is dipicted by an elevated Michaelis-Menten's hyperbola in fig 2 . The $K_{m}$ values were all within the normal range.

\section{Discussion}

The results of the present investigation show that workers exposed to solvents and organic isocyanates differ as a group from nonexposed referents with regard to the transport of serotonin in platelets. Although the serotonin transport strictly obeyed Michaelis-Menten's simple saturation kinetics, the $V_{\max }$ values of the majority of the workers were significantly higher than those of the referents. The platelet count was below the lower limit of the tolerance interval in three of the twelve subjects, and on the average the platelet numbers were lower in the exposed group than in the reference group.

Solvents such as toluene, xylene, and white spirit are present in many paint mixtures. In addition organic isocyanates are often one of the components in the frequently used hardeners. The total daily exposure may consist of synergistic and/or cumulative effects from inhalation and skin adsorption of the different agents (11, 19). It is therefore difficult to discriminate between the impact of the different solvents and isocyanates on the organism.

Humans with evident symptoms of intoxication from benzene, toluene, or xylene show a decreased number of leucocytes and platelets. The reduction is considered to be due to an impaired cell regeneration function of the bone marrow $(20,29)$. The platelet count of the exposed subjects in the present investigation was lowered as compared to that of the referents. The workers did not, however, complain of the symptoms, like fatigue or headaches, usually related to exposure to organic solvents. We find it unlikely that the subjects, in their modern and wellventilated environment, should suffer damage to the bone marrow. 
The intrinsic metabolic activity of the platelet and the composition of the plasma environment influence the serotonin uptake both in quality and in quantity ( 8 , 15). The normal platelet population shows heterogeneity in both cell size and density. Platelets newly released from the bone marrow are heavy and large, while older platelets are lighter and smaller. The heavy and large cells have a higher metabolic activity and have been shown to have an increased serotonin uptake rate (8). An increased platelet turnover and a subsequent shift towards a younger platelet population should thus result in an increase in $V_{\max }$. a phenomenon which we found in nine of our solvent-exposed subjects. In case of a normal platelet turnover in the solventexposed individuals, the rise in $\mathrm{V}_{\max }$ would imply that the number of membranebound serotonin carrier molecules per platelet have been increased.

It is well known that organic solvents and their metabolites affect the neuronal membrane $(22,24)$. The platelet is accepted as an appropriate model cell for a presynpatic neuron. A similar influence on the platelet membrane of solvent metabolites might therefore be possible and may be an alternative explanation for the aberrent serotonin transport.

Organic isocyanates in the work environment may induce marked irritation in the respiratory tract and on mucous membranes, but the mechanism behind their toxicity is not clear. The investigated workers neither exhibited asthmatic symptoms nor the aberrant serotonin kinetic characteristics for endogenous asthma. Organic isocyanates react in vitro with free amino groups and other sites in proteins $(6,28)$. Hexamethylenediisocyanate was present in the hardeners used by our workers. In preliminary in vitro experiments we have not found that hexamethylenediamine, a hydrolysis product from hexomethylenediisocyanate in final plasma concentrations of $10^{-8}, 10^{-6}$, and $10^{-4} \mathrm{~mol} / \mathrm{l}$, alters the serotonin uptake in platelets from healthy volunteers.

Although the mechanisms behind the aberrent serotonin transport in platelets from the investigated workers remain obscure, we are inclined to believe that the solvents play a major role. The present method for determining serotonin transport may indicate very slight and initial organ damage caused by solvents and solvent metabolites prior to the appearance of clinical symptoms.

\section{Acknowledgments}

This work was supported by grant $81-$ 0194 from the Swedish Environment Fund. The skillful technical assistance of Ms M Wåhlin and Ms S Berneby is greatly appreciated.

\section{References}

1. Born C. Current ideas on the mechanism of platelet aggregation. Ann ny acad sci 201 (1972) 4-12.

2. Born GVR, Gillson RE. Studies on the uptake of 5-hydroxytryptamine by blood platelets. J physiol (London) 146 (1959) 472.

3. Charles J, Bernstein A, Jones B, Jones DJ, Edward JH, Seal RME, and Seaton A. Hypersensitivity pneumonitis after exposure to isocyanates. Thorax 31 (1976) $127-136$.

4. Costa J, Murphy DL. Platelet 5-HT uptake and release stopped rapidly by formaldehyde. Nature 255 (1975) 407-408.

5. Elofsson S-A, Gamberale F, Hindmarsh T, Iregren A, Isaksson A, Johnsson I, Knave B, Lydahl E, Mindus P, Persson HE, Philipson B, Steby M, Struwe G, Söderman E, Wernberg A, Widén L. Exposure to organic solvents: A cross-sectional epidemiologic investigation on occupationally exposed car and industrial spray painters with special reference to the nervous system. Scand j work environ health 6 (1980) $239-273$.

6. Gage JC. The subacute inhalation toxicity of 109 industrial chemicals. $\mathrm{Br} \mathrm{j}$ ind med 27 (1970) 1-18.

7. Goodman LS, Gilman A, ed. The pharmacological basis of therapeutics. Fifth edition. MacMillan Publishing Co, New York, NY $1975, p 905$.

8. Karpatin S. Heterogeneity of human platelets: Metabolic and kinetic evidence suggestive of young and old platelets. Ser haematol 4 (1975) 75-97.

9. Lineweaver A, Burk D. Determination of enzyme dissociation constants. J am chem soc 56 (1934) 666-- 685 .

10. Lingjaerde O. Platelet uptake and storage of serotonin. In: Essman WB, ed. Serotonin in health and disease. Volume IV. Spectrum Publications, New York, NY 1978.

11. Malkinson FD, Gehlman L. Factors affecting percutaneous adsorption. In: Drill VA, Lazar P, ed. Cutaneous toxicity. Academic Press Inc, New York, NY 1977, pp 63-81.

12. Malmgren R. Methodological aspects of studies on the 5-HT uptake mechanism in normal platelets. Acta pharmacol toxicol 49 (1981) 277-284.

13. Malmgren R, Ásberg M, Olsson P, Tornling $G$, Unge G. Defective serotonin transport mechanism in platelets from endogenously depressed patients. Life sci 29 (1981) 2649- 
2658.

14. Malmgren R, Grubbström J, Theorell H, Tornling $\mathrm{G}$, Unge $\mathrm{G}$. Defective serotonin (5-HT) transport mechanism in platelets from patients with endogenous and allergic asthma. Allergy 37 (1982) 29-39.

15. Malmgren $R$, Olsson $P$, Unge $G$. The effect of various inhibitors of the 5-HT binding and uptake by human platelets. Thrombosis res 22 (1981) $469-480$.

16. National Institute for Occupational Safety and Health. Occupational exposure to isocyanates. US Department of Health Education and Welfare, Cincinnati, OH 1979.

17. Peters JM, Wegman DH. Epidemiology of toluene diisocyanate (TDI)-induces respiratory disease. Environ health perspect 11 (1975) 97-100.

18. Pletscher A, Laubscher A. Blood platelets as models for neurons: Uses and limitations. J neural transm suppl 16 (1980) 7-16.

19. Riihimäki V, Pfäffli P. Percutaneous adsorbtion of solvent vapors in man. Scand j work environ health 4 (1978) $73-85$.

20. Robbins SL. Pathological basis of disease. WB Saunders. Philadephia, PA 1974, p 740.

21. Rodbard D. Mathematics of hormonereceptor interactions. In: O'Malley $\mathrm{BO}$, Means AR, ed. Advances in experimental medicine and biology. Volume 26. Plenum Press, New York, NY 1973, pp 289-326.

22. Savolainen $\mathbf{H}$. Some aspects of the mechanisms by which industrial solvents produce neurotoxical effects. Chem biol interact 18 (1977) $1-10$.

23. Scatchard G. The attraction of proteins for small molecules and ions. Ann ny acad sci 51 (1949) 660-672.

24. Schaumburg $H$, Spencer $P$. The neurology and neuropathology of the occupational neuropathesis. J occup med 18 (1976) $739-$ 742 .

25. Sips R. On the structure of a catalyst surface. J chem phys 16 (1948) 480-495.

26. Sneddon JM. Blood platelets as a model for monoamine-containing neurons. In: Kerkut GA, Phillips JW, ed. Progress in neurobiology. Volume 1. Pergamon Press, Oxford 1973, pp 151-192.

27. Stahl MS, Meltzer HY. A kinetic and pharmacologic analysis of 5-hydroxytryptamine transport by human platelets and platelet storage granules: Comparison with central serotonergic neurons. J pharmacol exp ther 205 (1978) 118-131.

28. Ted Tse CS, Pesce AJ. Chemical characterization of isocyanate-protein conjugates. Toxicol appl pharmacol 51 (1979) 39-46.

29. Wirth W, Hecht G, Gloxhuber C, ed. Toxikologie-Fibel. Georg Thieme, Stuttgart 1976, pp 192-194.

30. Zapp JA. Hazards of isocyanates in polyurethane foam plastic production. Arch ind health 15 (1957) $324-330$.

Received for publication: 20 September 1982 